0.45 and 0.48 p.p.m. after 33 and 34 weeks of continued treatment. It seems certain, ther, that the fluid environment of cells cannot reach the fluoride concentrations which are required to inhibit cell growth of those cells that have been studied under in vitro conditions.

\section{Summary}

Sodium fluoride was added in known amounts to cultures of HeLa and human oesophageal cells, and the multiplication of the cells was determined by cell counts carried out by an operator who was unaware of the fluoride contents of the media. Amounts of added fluoride up to 4.5 p.p.m. did not affect the multiplication of HeLa cells when the fluoride was added to the media at the same time as the media were inoculated with the cells. No effect on cell multiplication or on protein synthesis was fcund by up to 10 p.p.m. added fluoride with HeLa cells or oesophageal cells. At 15 p.p.m. added fluoride an incipient retardant effect on growth of oesophageal epithelial cells was noted.
These results indicate that higher fluoride concentrations than those found in human body fluids are required, under in vitro conditions, to alter epithelial cell growth.

This work was supported by Grant DE-01850, National Institute of Dental Research, and by Grant AI-04729, National Institute of Allergy and Infectious Diseases, Bethesda, Maryland.

\section{REFERENCES}

Albright, J. A. (1964). Nature (Lond.), 203, 976.

Armstrong, W. D. (1960). Arch. oral. Biol., 4, 156. Singer, L., Ensinck, J., and Rich, C. (1964). F. clin. Invest., 43, 555.

Berry, R. J., and Trillwood, W. (1963). Brit. med. F., 2, 1064

Eagle, H. (1959). Science, 130, 432

Gey, G. O., Coffman, W. D., and Kubicek, M. T. (1952). Cancer Res.,

McLaren, L. C., Holland, J. J., and Syverton, J. T. (1959). F. exp. Med., 109, 475 .

Oyama, V. I., and Eagle, H. (1956). Proc. Soc. exp. Biol. (N.Y.), 91,

Proffit, W. R., and Ackerman, J. L. (1964). Science, 145, 932.

Singer, L., and Armstrong, W. D. (1954). Analyt. Chem., 26, 904. - (1960). 7. appl. Physiol., 15, 508.

- (1962). 7. dent. Res., 41, 910.

Syverton, J. T., and McLaren, L .C. (1957). Cancer Res., 17, 923.

\title{
New Observations on Distribution of Neoplasms of Female Breast in Certain European Countries
}

\author{
A. J. LEA,* M.B., CH.B.
}

Brit. med. F., 1965, 1, 488-490

It must first be made clear that we are here dealing with death rates from neoplasms as distinct from their incidences, which unfortunately are not known. However, treatment of neoplasms of the breast does not vary greatly from one country to another, so that errors introduced by such differences as do exist are likely to be small and not greatly to influence the results.

The very low death rate from neoplasms of the breast in Japanese women as compared with the rates for women in western Europe has been known for some years (Segi, 1955). Various explanations, ranging from differences in breastfeeding habits (Stocks, 1958) to racial factors (Steiner, 1954), have been suggested to account for this. If the difference were due mainly to racial factors, then it might show in the distribution of these neoplasms in a country in which part of the population was of Mongoloid origin and part of European, provided that the two sections of the population could be distinguished geographically and that such distinction corresponded with the method of recording the vital statistics. Such a country is Finland, where the Lapp population in the north has a Mongoloid origin, and where the death rate from neoplasms of the breast is known to be low for the whole country (Segi and Kurihara, 1962). Unfortunately, the necessary data for Finland were not readily available, but those for Norway and Sweden were to hand. It was known that the death rates for neoplasms of the breast in these countries, though higher than in Finland, were considerably lower than for Western Europe in general (Segi and Kurihara, 1962). It was also known that part of the population in the north of these countries was of Lapp origin (Coon, 1939).

Examination of crude death rates from neoplasms of the breast for the individual counties of Norway and Sweden

* Statistics Unit, Imperial Cancer Research Fund, London. showed that wide variations existed in both countries, the rates in the north being much less than those in the south. By pooling the data for the two countries and plotting it against the mean latitude of the various counties it was apparent that the gradient ran fairly smoothly from north to south. Addition of similar data for England and Wales and Scotland showed that the gradient continued south to the Channel Islands. This result was very surprising, but improvement of the data by using all available for a nine-year period, correcting for age distribution and constructing a mortality index for the latitude range of $50^{\circ}$ to $70^{\circ}$ North, merely had the effect of smoothing out some of the irregularities. It was found that the probability of the correlation between the mortality index and the mean latitude being due to chance was less than 1 in 1,000 . It was obvious that these results could not be explained by a Mongoloid origin of part of the population.

Factors which might be associated with latitude were considered, the obvious one being temperature. It was found possible to make an estimate of the mean annual temperature for each degree of latitude for the countries under investigation from data published by the Meteorological Office. A high degree of correlation between mean annual temperature and mortality rate from neoplasms of the breast $(P<0.001)$ was found. However, for London, the area providing the largest population and most reliable statistics on death rates, the published mean temperature was much lower than it should have been to fit the hypothesis. A check from the individual monthly values showed that the annual maximum was $10^{\circ} \mathrm{F} .\left(5.5^{\circ} \mathrm{C}\right.$.) too low, and correction of this entirely removed the apparent discrepancy.

If the association between mean annual temperature and death rate from neoplasms of the breast held good for the rest of the world, then it was obvious that populations living in the extreme 
north would know very little of the disease and that there would be a very high death rate from it at the Equator. The data that were available, especially those for Japan, made it clear that the association did not continue much beyond a mean annual temperature of $51^{\circ} \mathrm{F}$. $\left(10.6^{\circ} \mathrm{C}\right.$.).

\section{Material and Methods}

The data used were obtained from the official statistical publications of Norway, Sweden, and Great Britain (Norges Offisielle Statistikk, 1950-61 ; Sveriges Officiella Statistik, 1950-61 ; Registrar-General's Statistical Review of England and Wales, 1953-61 ; Registrar-General's Annual Report for Scotland, 1953-61). The years used were 1953 to 1961 inclusive, this being determined by changes in definition which took place at the General Registry Office in 1953 and data later than for 1961 not being readily available to us for Norway and Sweden. The census years were not the same for all the countries, being 1950 and 1960 for Norway and Sweden and 1951 and 1961 for Great Britain.

The female populations were divided into the age-groups $0-24,25-34,35-44,45-54$, and 65 years and over. The total number of deaths from neoplasms of the breast in each agegroup for England and Wales as a whole for the nine years under investigation was found, and also the female population at risk in each age-group for this period. From these figures age-specific death rates for neoplasms of the breast for England and Wales for the period 1953-61 were calculated.

The female population for each age-group for each region in England and Wales and each county in Scotland, Norway, and Sweden was noted for each census year, a mean value calculated for each age-group, and these figures were taken as the basic population at risk for the nine years under review. Using the age-specific death rates for England and Wales as standards, the expected deaths for each county or region, assuming all to have the same death rates, were then calculated. It was then possible to construct a mortality index for the whole area by taking the deaths for England and Wales as a whole as being 100.

The extremes of latitude of each county or region were noted on appropriate maps (Geographia Map of the British Isles, and Stanford's .General Map of Scandinavia). The means of these extremes were calculated and the assumption was made that for the purposes of this investigation the population of each area was concentrated at these mean latitudes. The mean latitudes were then rounded up to the nearest degree, the population and deaths from neoplasms of the breast for each degree of latitude were pooled regardless of their country of origin, and a latitude range from $50^{\circ}$ to $70^{\circ}$ North was obtained, with corresponding mortality indices for neoplasms of the breast.

The average maximum and minimum temperatures for the year for a large number of places, for each of which the latitude and height above sea-level are also given, are published by the Meteorological Office (Air Ministry, 1959). The mean of the average maximum and minimum temperature for each degree of latitude in the area under investigation was calculated, and this figure taken as the mean annual temperature. As height above sea-level has a marked influence on temperature, only places below $500 \mathrm{ft}$. $(152 \mathrm{~m}$.) above sea-level were used, it being assumed for the present work that the population in general lives within this altitude range. The resulting mean annual temperatures were correlated with latitude and with the mortality indices for neoplasms of the breast. (It will be noted that a mortality index is given for 18 latitudes in Table I, but for only 16 mean annual temperatures in Table II. This is because for two of the latitudes in Table I the Meteorological Office does not publish data on temperatures.)

Only simple arithmetical procedures were used, with the standard methods of calculation of the correlation coefficient " $r$ " and of the "best straight line."

\section{Results}

The mortality indices and the corresponding mean latitudes are shown in Table I. Table II shows the mortality indices and the corresponding mean annual temperatures irrespective of the country concerned. Fig. 2 is their graphical representation with the best straight line.

TABLE I.-Mean Latitude and Mortality Indices for Neoplasms of the

\begin{tabular}{|c|c|c|c|}
\hline \multicolumn{3}{|c|}{ Mean Latitude } & Mortality Index \\
\hline $\begin{array}{l}\text { England and Wales } \rightarrow \\
\text { Scotland } \rightarrow\end{array}$ & $\begin{array}{l}50 \\
51 \\
52 \\
53 \\
54 \\
55 \\
56 \\
57 \\
58 \\
59 \\
60 \\
61 \\
62 \\
63 \\
64 \\
65 \\
66 \\
67 \\
68 \\
69 \\
70\end{array}$ & $\leftarrow$ Sweden & $\begin{array}{r}102.5 \\
104.5 \\
100.4 \\
95.9 \\
87.0 \\
95.0 \\
88.6 \\
89.2 \\
78.9 \\
84.6 \\
81.7 \\
72.2 \\
65.1 \\
68.1 \\
82.5 \\
60.5 \\
\\
67.3 \\
52.5\end{array}$ \\
\hline
\end{tabular}

The blank spaces in the column of indices indicate those mean latitudes for which data were not available. Correlation: $r=-0.9210, n=16, P<0.001$.
Fig. 1 is the graphical representation of the above data, with the best straight line.

TABLE II.-Mean Annual Temperature and Mortality Indices for Neoplasms of the Female Breast. Norway, Sweden, and Great Britain

\begin{tabular}{c|c|c|c}
\hline $\begin{array}{c}\text { Mean Annual } \\
\text { Temperature }\end{array}$ & $\begin{array}{c}\text { Mortality } \\
\text { Index }\end{array}$ & $\begin{array}{c}\text { Mean Annual } \\
\text { Temperature }\end{array}$ & $\begin{array}{c}\text { Mortality } \\
\text { Index }\end{array}$ \\
\hline 51.3 & 102.5 & 46.3 & 78.9 \\
49.9 & 104.5 & 42.1 & 84.6 \\
50.0 & 100.4 & 44.2 & 81.7 \\
49.2 & 95.9 & 43.5 & 72.2 \\
48.5 & 87.0 & 42.3 & 65.1 \\
47.8 & 95.0 & 40.2 & 68.1 \\
47.3 & 88.6 & 31.8 & 67.3 \\
45.1 & 89.2 & 34.0 & 52.5 \\
\hline
\end{tabular}

Correlation: $\mathrm{r}=0.8797, \mathrm{n}=14, \mathrm{P}<0.001$.

\section{Discussion}

It has now been established that a very highly significant correlation $(P<0.001)$ exists between the death rate from neoplasms of the breast in females and mean annual temperature (this latter being a function of latitude) for Norway, Sweden, and Great Britain, the death rate increasing with rise of mean annual temperature. Hypothetical racial differences were clearly unable to explain the facts. No reasonable explanation presented itself and there was a possibility that the whole effect could be an artifact, though the nature of such an artifact could only be surmised. On the other hand, whatever the explanation might be, the association was sufficiently real for it to disclose an error in the published tables of temperatures, and this greatly diminished the possibility of an artifact.

The effect of latitude on the death rates from neoplasms of the uterine cervix and of the body of the uterus and appendages was investigated in precisely the same way, using the same sources of data. No similar pattern, or indeed any pattern other than a random distribution, was found. This made the possibility of an artifact very unlikely.

It is generally recognized that the methods of recording vital statistics vary from one country to another, and that it is doubtful if the data of any two countries can be regarded as strictly comparable. On the other hand, since the World Health Organization began publication of Epidemiological and Vital Statistics in 1948 much attention has been paid to these differences and there has been a general improvement in the situation. There is no doubt that these differences have at times been exaggerated and used as a convenient means of explaining away embarrassing published statements-for 
example, the low death rate from cancer of the breast in Japanese women. Nevertheless they still exist and must be kept in mind. Also, as pointed out previously, these data refer to death rates and not to the incidence of these neoplasms.

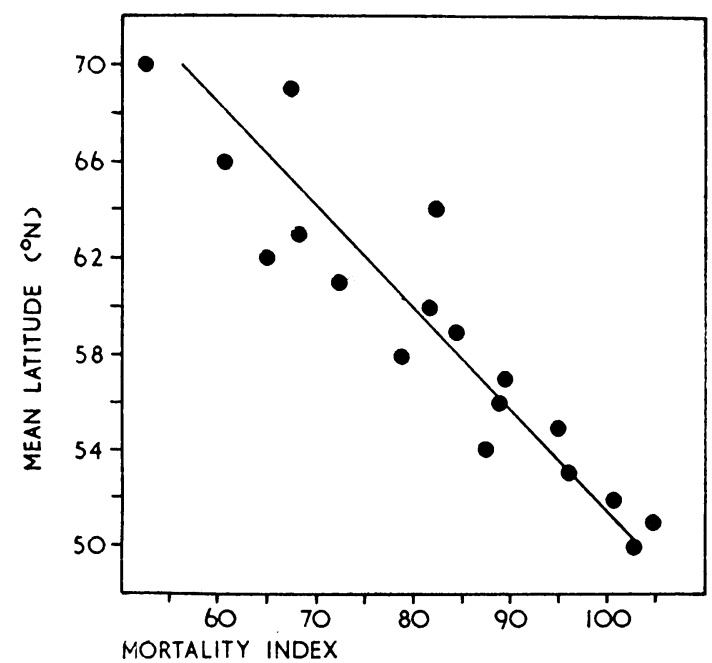

FIG. 1.-Mean latitude and mortality indices for neoplasms of the female breast. Norway, Sweden, and Great

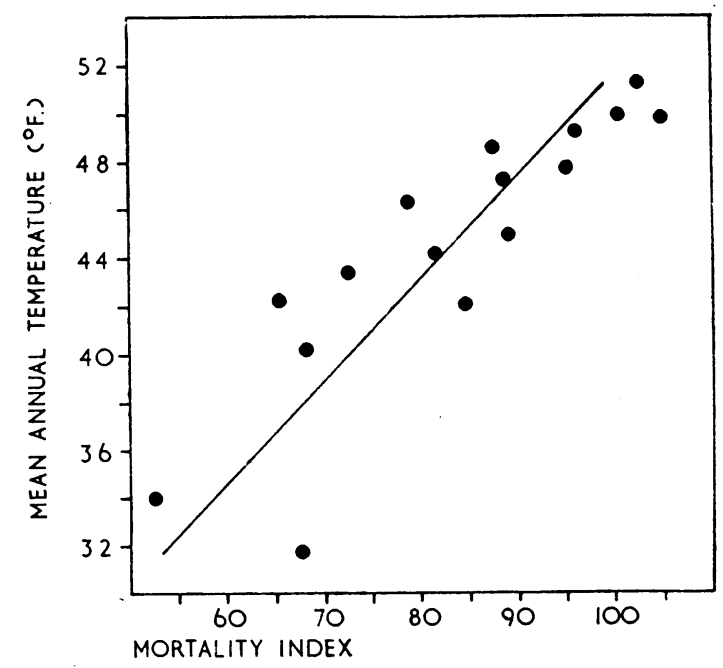

FIG. 2.-Mean annual temperature and mortality indices for neoplasms of the female breast. Norway, Sweden, and Great Britain.

The method of obtaining mean annual temperature and the assumption that the population lives at that temperature are clearly very crude procedures and must have introduced errors. No doubt it would be possible to improve the accuracy of these figures and perhaps obtain details of both temperature and cancer death rates for areas as small as cities. However, the correlation between the mortality index and the mean annual temperature for those areas for which details were available was so remarkably significant and of so much general interest that publication of the results at this stage was deemed to be advisable. With such a correlation further details would have to be of an extraordinary nature to contradict these findings.

The nature of the factor or factors concerned in the aetiology of neoplasms of the breast, which appear to be more active in the temperate zone than in regions with a lower mean annual temperature, is at present a matter for speculation. This investigation is now being extended to include all countries for which information on death rates is available.

\section{Summary}

An association between the death rate from neoplasms of the breast in females and mean annual temperature has been found.

The nature of this association is that the death rate increases with the mean annual temperature.

These findings apply, at present, only to Norway, Sweden, and Great Britain.

The evidence does not, at this stage, allow a statement on the nature of the factor or factors concerned to be made.

The investigation is being extended to all countries for which information is available.

I am indebted to Dr. W. Williams, M.O.H. for Jersey, for providing data on the Channel Islands, and to Dr. G. F. Marrian, Director of Research, Imperial Cancer Research Fund, for his advice and helpful criticism.

\section{REFERENCES}

Air Ministry, Meteorological Office (1959). Tables of Temperature, Relative Humidity and Precipitation for the World, Part III. H.M.S.O., London.

Coon, C. S. (1939). The Races of Europe. Macmillan, New York.

Norges Offisielle Statistikk (1953-61). Medical Statistical Report. Statistisk Sentralbyra, Oslo.

(1950). Population Census 1960. Statistisk Sentralbyra, Oslo.

Registrar-General for England and Wales (1953-61). Statistical Review of England and Wales, Part 1: Tables, Medical. H.M.S.O., London.

Registrar-General for Scotland (1953-61). Annual Reports. H.M.S.O., London.

Segi, M. (1955). Cancer Mortality Statistics in Japan. Tohoku University, Sendai, Japan.

- and Kurihara, M. (1962). Cancer Mortality for Selected Sites in 24 Countries, No. 2. Tohoku University, Sendai, Japan.

Steiner, P. E. (1954). Cancer, Race and Geography. Williams and Wilkins, Baltimore.

Stocks, P. (1958). In Cancer, Vol. 3, p. 184. Butterworth, London.

Sveriges Officiella Statistik (1953-61). Medical Statistical Report. Statistiska Centralbyra, Stockholm.

(1950, 1960). Population Census. Statistiska Centralbyra, Stockholm. 